\title{
Esophagus and Esophagogastric Junction Cancer pM1 TNM Finding v8
}

National Cancer Institute

\section{Source}

National Cancer Institute. Esophagus and Esophagogastric Junction Cancer pM1 TNM

Finding v8. NCI Thesaurus. Code C133372.

Esophagus and esophagogastric junction cancer with distant metastasis. (from AJCC 8th Ed.) 